\title{
Care Behaviors of Nursing Students and the Influencing Factors: A Comparative Study
}

\author{
Özlem AKMAN*, Candan ÖZTÜRK***
}

\begin{abstract}
Aim: This study was conducted to determine the care behavior perceptions of Turkish and foreign students who were continuing their education in Turkey and the Turkish Republic of Northern Cyprus as well as the influencing factors and if there was a difference between their care behavior perceptions.
\end{abstract}

Method: The sample of the descriptive and correlational study was composed of the nursing students of a Foundation University in Istanbul and a university in the Turkish Republic of Northern Cyprus (TRNC). 651 students who agreed to participate in the study were included in the study. The data were collected with Student Information Form and Care Behaviors Inventory24 (CBI-24). Frequency, mean, standard deviation, Kolmogorov-Smirnov test, Shapiro Wilk-W test, Mann-Whitney U test, and Kruskal-Wallis test were used to analyze the data.

Results: It was determined that the mean age of the students was 21,30 $\pm 2,92$. CBI-24 mean scores of the students were $5,22 \pm 0,70$. CBI-24 mean score of the students who were willing chose the nursing profession, stated that caregiving is the main task of the nurse, and had the experience of giving and receiving the care was found to be higher $(p<0.05)$.

\section{Özgün Araştırma Makalesi (Original Research Article)}

Geliş / Received: 25.01.2021 \& Kabul / Accepted: 09.08.2021

DOI: https://doi.org/10.38079/igusabder.867994

* Assist. Prof. Dr., Istanbul Aydin University, Faculty of Health Sciences, Nursing Department Istanbul, Turkey, E-mail: akmanmert2011@gmail.com ORCID https://orcid.org/0000-00031460-3251

** Prof. Dr., Near East University, Faculty of Nursing, Nicosia TRNC Mersin 10, Turkey, E-mail: candan.ozturk@neu.edu.tr ORCID https://orcid.org/o000-0002-0909-5013

ETHICAL STATEMENT: In order to conduct the study, approval (YDU/2018/62-650, O2/O2/2O19 dated and 2019/O4 numbered / and 21/O1/2O2O-E.385 dated and 20292139050.01.04 numbered) was obtained from the Ethics Committees of both universities. Before the application, the participants were informed about the study and their verbal and written consents were obtained. 
Conclusion: It was determined that the care behaviors perceptions of the students were in a good level and the care behaviors perceptions of the students were affected by the factors like gender, grade, nationality, preferring the profession willingly, feeling sufficient about understanding patients and choosing the nursing profession again if they had another chance. In line with these results, it is recommended to ensure that students willingly prefer the profession and to carry out practices to ensure the continuity of positive care behaviors of students during the nursing education.

Keywords: Care behaviors, nursing students, nursing care.

\section{Hemşirelik Öğrencilerinin Bakım Davranışları ve Etkileyen Faktörler: Karşılaştırmalı Bir Çalışma}

\section{$\ddot{O} \mathbf{z}$}

Amaç: Bu çalışma ile Türkiye ve Kuzey Kıbrıs Türk Cumhuriyeti’nde öğrenimine devam eden Türk ve yabancı uyruklu öğrencilerin bakım davranışı algılarını, etkileyen faktörleri ve öğrenciler arasında bakım davranışı algılarında fark olup olmadığını belirlemek amacıyla gerçekleştirildi.

Yöntem: Tanımlayıcı ve ilişki arayıcı tipte yapılan araştırmanın örneklemini İstanbul'da bir Vakıf Üniversitesi ile Kuzey Kıbrıs Türk Cumhuriyeti (KKTC)'deki bir üniversitenin hemşirelik öğrencileri oluşturmuştur. Çalışmaya katılmayı kabul eden 651 öğrenci araştırmaya dahil edilmiştir. Veriler Öğrenci Tanıtım Formu ve Bakım Davranışları Ölçeği-24 (BDÖ-24) ile toplanmıştır. Verilerin analizinde frekans, ortalama, standart sapma, Kolmogorov-Smirnov, Shapıro Wilk-W testi, Mann-Whitney U ve Kruskal-Wallis testi kullanılmıştır.

Bulgular: Öğrencilerin yaş ortalaması 21,30 $\pm 2,92$ 'dir. Öğrencilerin BDÖ-24 ortalama puanı $5,22 \pm 0,70$ 'dir. Hemşirelik mesleğini isteyerek seçen, bakım vermenin hemşirenin temel görevi olduğunu belirten, bakım verme ve bakım alma deneyimi olan öğrencilerin BDÖ-24 ortalama puanının daha yüksek olduğu bulunmuştur ( $\mathrm{p}<0.05)$.

Sonuç: Öğrencilerin bakım davranışları algılamalarının iyi düzeyde olduğu; öğrencilerin bakım davranışları algılamalarını cinsiyet, sınıf, uyruk, mesleği isteyerek tercih etme, hastaları anlama konusunda kendilerini yeterli hissetme ve başka seçeneğini olsa yine de hemşirelik mesleğini seçme gibi faktörlerin etkilediği belirlenmiştir. Bu sonuçlar doğrultusunda; öğrencilerin mesleği isteyerek tercih etmelerinin sağlanması; hemşirelik eğitimi süresince öğrencilerin olumlu bakım davranışlarının sürekliliğinin sağlanmasına yönelik uygulamaların yapılması önerilmektedir.

Anahtar Kelimeler: Bakım davranışları, hemşirelik öğrencileri, hemşirelik bakımı. 


\section{Introduction}

Care is a multidimensional phenomenon that begins with the history of humanity, has been defined in various forms but has no single definition. It is a concept that is not specific only for nursing but unique for nursing and an occupation made by nurses ${ }^{1,2}$. Nursing care is generally based on the communication between the healthy/sick individual and the nurse and includes relieving the individual with a holistic approach, helping him/her to find peace, and meeting basic human needs ${ }^{1,3}$. In addition to this definition, many theorists defined the care concept with different perspectives. For example, it was defined to cover "delivery of beneficial service, a moral behavior and ethical obligation" by Fry, "ensuring education and learning activities of the care of an individual" by Hall, "meeting the needs of an individual when he/she cannot meet his/her own self-care needs" by Orem, "helping and supporting in meeting the requirements of a group whose needs were determined and having the professional knowledge, skills and behaviors to do so" by Leininger ${ }^{4}$. Leininger also expresses that as a teaching forming the basis of nursing practices, care is at the center of nursing that is a profession containing a value-belief system ${ }^{5}$. Henderson emphasizes that the physical, psychological, cultural, intellectual and social aspects of the patients should be considered by the nurse while realizing care action and states that the nurse should have the values of helping and empathizing ${ }^{6}$. In this context, when the concept of nursing care and characteristics are examined, it is seen that the concept includes physical, psychological, social and spiritual interventions of the person. Therefore, it is very difficult to define the concept $t^{1,7}$. Nursing care, which contains a basic foundation and originality for nurses and has many dimensions, is affected by professional and individual characteristics of nurses as well as many social, political, economic and institutional factors. On the other hand, understanding the scope of the nursing care concept constituting the essence of nursing is very important in terms of comprehending nursing, understanding its philosophy and abandoning the practices that are not included in the care concept.

Developments in technology and social changes from past to present have caused nurse roles to change and differentiate. This made it necessary for nurses to make more complex decisions in the care process. Therefore, the nurse must have sufficient professional knowledge and skill, follow scientific and medical developments, be open to 
change, take responsibility and adopt professional ethical values. Therefore, it becomes important to teach theoretical and clinical practices with care and care-related attitudes and behaviors within nursing education programs. Basset stated that the knowledge and experiences gained by nursing students during their education process have a crucial effect on taking responsibility and adapting their roles about nursing care and practices ${ }^{8}$. In their study, Murphy et al investigated "the effect of nursing education on care behaviors of nursing students", and determined that third-year students had lower care behavior scores compared to the first-year students and the education process decreased their care behaviors 9 . In another study, care behaviors of the third-year students were better than those of the first-year students ${ }^{10}$. Care is a basic nursing value and a desirable feature in nursing students. Therefore, professional education should be established on the basis of care. The aim of this study was to determine the care behavior perceptions of Turkish and foreign students continuing their education in Turkey and the Turkish Republic of Northern Cyprus as well as the influencing factors and whether or not there is a difference between the students in their care behavior perceptions.

In this study, the answers to the following questions were sought:

1- What are the nursing students' perceptions of care behavior?

2- What are the factors affecting nursing students' perceptions of care behavior?

3- Is there a difference between Turkish and foreign students' perceptions of care behavior?

\section{Material Methods}

\section{Place of the Study}

The descriptive study was conducted with the students of the nursing undergraduate program of two universities (Istanbul/Turkey, Nicosia/TRNC) between October 2018 and June 2019.

\section{Participants and Procedures}

The target population of the study was composed of nursing students studying in the Nursing departments of both universities $(n=1100)$. In the study, no sampling method was used and 651 students, who agreed to participate in the study, completed at least one 
half-year clinical practice and attended classes on the days when the data were collected, were included in the study. The questionnaire was applied to each class on different days and during the times other than students' classes. Before the application of the questionnaire, the students were informed. The questionnaire was delivered to the students who agreed to participate in the study and they were asked to fill out it under the supervision of the researchers. The application of the questionnaire took an average of 15 minutes.

\section{Ethical Considerations}

In order to conduct the study, approval (YDU/2018/62-650, 02/02/2019 dated and 2019/o4 numbered / and 21/01/2020-E.385 dated and 20292139-050.01.04 numbered) was obtained from the Ethics Committees of both universities. Before the application, the participants were informed about the study and their verbal and written consents were obtained.

\section{Data Collection Tools}

Student Information Form; Student Information Form is composed of thirteen questions (age, gender, class level, family type, hospitalization status, working experience as a nurse, status of taking care of an elderly/a baby or a patient, status of feeling self-competent in understanding patients, and status of selecting the profession willingly, etc.).

Care Behaviors Inventory-24 (CBI-24); This scale prepared by Wu et al. ${ }^{11}$ is the short form of "Care Behaviors Inventory-42 (Caring Behaviors Inventory-42)" containing 42 items suitable for bidirectional diagnosis by patients and nurses developed by Wolf et al. ${ }^{11}$. Turkish reliability studies of the scale designed to evaluate the nursing care process were conducted by Kurşun and Kanan ${ }^{12}$.

The inventory was designed to evaluate the nursing care process. CBI-24 is used to compare the nurses' self-assessment and their patient perceptions ${ }^{11}$. In addition, the inventory is also used to evaluate nursing care (resting, training, care behaviors covering also the patient in decision making) given in the pre-and post-surgical intervention period. 
Care Behaviors Inventory is composed of 24 items and 4 subscales including assurance ( 8 items $=16,17,18,20,21,22,23,24)$, knowledge-skill ( 5 items $=9,10,11,12,15)$, respect (6 items $=1,3,5,6,13,19$ ), and adherence ( 5 items=2,4,7,8,14). 6-point Likert-type scale ( $1=$ never, $2=$ almost never, $3=$ sometimes, $4=$ usually, $5=$ often, $6=$ always) is used for the answers. The scale total score between 1-6 is obtained by summing all item scores (24 items) and dividing them into 24. For each subscale, subscale scores between 1-6 are obtained by dividing the score, obtained by summing the scores of the items in the subscale, into the number of items. As the subscale and total scale scores increase, the level of perception of the quality of care of patients or nurses increases ${ }^{12}$.

The scale is filled out by the patient and the researcher (individual or phone interview) or by the patient him/herself. The internal consistency of the scale for both patients and nurses is 0,96 on the overall scale and ranges between 0,82 and 0,92 in its subscales ${ }^{11}$. It was determined in the present study that Cronbach's alpha value was 0,91 for the overall scale and ranged between 0,88 and 0,92 for its subscales.

\section{Evaluation of the Data}

In the data assessment, IBM SPSS 25.0 (SPSS Inc., Chicago, IL, USA) packaged software was used. Firstly, Kolmogorov-Smirnov and Shapiro Wilk-W tests were performed in order to determine whether or not data showed normal distribution and normal distribution of data was examined. It was determined that the significance level of the obtained results was $p<0.05$ and the data were not normally distributed. In the literature, if it is $p<0.05$, this indicates that the data do not show normal distribution ${ }^{13}$. According to these results, nonparametric tests were applied. In the comparison of quantitative data, Mann-Whitney U test between two independent groups where the data were numerical, Kruskal-Wallis test between more than two independent groups where data were numerical and frequency, mean, and standard deviation values for descriptive statistics were used. In order to determine the cause of the difference, a post-hoc analysis was conducted. The results were evaluated at a confidence interval of $95 \%$ and significance level of $p<0.05$.

\section{Results}

It was determined as a result of the analysis of the data, the mean age of the participants was $21 \pm 2$, 57,5\% were Turkish, $35 \%$ were third-year students, $73 \%$ were female, $97,4 \%$ 
were single, $96,9 \%$ had no children, $71,9 \%$ had no siblings, $74 \%$ were living in a nuclear family and $52,8 \%$ had never been hospitalized. It was determined that $84,8 \%$ of the students had no working experience as a nurse, 56,4\% had taken care of an elderly/baby/patient before, and 52,8\% sometimes felt competent to understand the patients. It was also determined that $84 \%$ of the students chose to be a student nurse by their own willingness, and 66,4\% responded "yes" to the question "would they choose the nursing profession again if they had another chance" (Table 1).

Table 1. Descriptive characteristics of the students $(n=651)$

\begin{tabular}{|c|c|c|c|}
\hline \multicolumn{2}{|l|}{ Descriptive Characteristics } & \multirow{2}{*}{\begin{tabular}{|l|} 
Number \\
374
\end{tabular}} & \multirow{2}{*}{$\frac{\%}{57.5}$} \\
\hline \multirow{3}{*}{ Nationality } & Turk & & \\
\hline & Turkish Cypriot & 101 & $15 \cdot 5$ \\
\hline & Foreign National & 176 & 27.0 \\
\hline \multirow{4}{*}{ Education } & $1^{\text {st }}$ year & 123 & 18.9 \\
\hline & $2^{\text {nd }}$ year & 160 & 24.6 \\
\hline & $3^{\text {rd }}$ year & 228 & 35.0 \\
\hline & $4^{\text {th }}$ year & 140 & 21.5 \\
\hline \multirow{2}{*}{ Gender } & Female & 475 & 73.0 \\
\hline & Male & 176 & 27.0 \\
\hline \multirow{2}{*}{ Marital status } & Married & 17 & 2.6 \\
\hline & Single & 634 & 97.4 \\
\hline \multirow{2}{*}{ Status of having children } & Yes & 20 & 3.1 \\
\hline & No & 631 & 96.9 \\
\hline \multirow{2}{*}{ Status of having siblings } & Yes & 611 & 93.9 \\
\hline & No & 40 & 6.1 \\
\hline \multirow{5}{*}{ Family } & Nuclear & 482 & 74.0 \\
\hline & Extended & 119 & 18.3 \\
\hline & Single parent & 42 & 6.5 \\
\hline & Broken family & 6 & .9 \\
\hline & I live alone & 2 & .3 \\
\hline \multirow{2}{*}{ Previous hospitalization } & Yes & 307 & 47.2 \\
\hline & No & 344 & 52.8 \\
\hline \multirow{2}{*}{ Status of having experience as a nurse } & Yes & 99 & $15 \cdot 3$ \\
\hline & No & 552 & 84.8 \\
\hline \multirow{4}{*}{$\begin{array}{l}\text { Year of experience as a nurse for those } \\
\text { who said yes }\end{array}$} & $<6$ months & 45 & 6.9 \\
\hline & $>1$ year & 28 & $4 \cdot 3$ \\
\hline & $>3$ years & 13 & 2 \\
\hline & $>5$ years & 1 & .2 \\
\hline
\end{tabular}




\begin{tabular}{|l|l|l|l|}
\hline & Unspecified & 12 & 1.8 \\
\hline \multirow{2}{*}{$\begin{array}{l}\text { Status of taking care of a baby/elderly } \\
\text { or a patient before }\end{array}$} & Yes & 367 & 56.4 \\
\cline { 2 - 4 } & No & 284 & 43.6 \\
\hline \multirow{2}{*}{$\begin{array}{l}\text { Status of feeling competent about } \\
\text { understanding patients }\end{array}$} & Always & 297 & 45.6 \\
\cline { 2 - 4 } & Sometimes & 344 & 52.8 \\
\cline { 2 - 4 } & Never & 10 & 1.5 \\
\hline \multirow{2}{*}{$\begin{array}{l}\text { Status of choosing to be a student } \\
\text { nurse by their own willingness }\end{array}$} & Yes & 548 & 84.2 \\
\cline { 2 - 4 } & No & 103 & 15.8 \\
\hline \multirow{2}{*}{$\begin{array}{l}\text { Status of selecting nursing profession } \\
\text { again if he/she had another chance }\end{array}$} & Yes & 432 & 66.4 \\
\cline { 2 - 4 } & No & 219 & 33.7 \\
\hline Mean Age (Mean \pm Sd) & Total & $\mathbf{6 5 1}$ & $\mathbf{1 0 0}$ \\
\hline
\end{tabular}

When the mean score of the subscales of the scale was examined, it was found to be

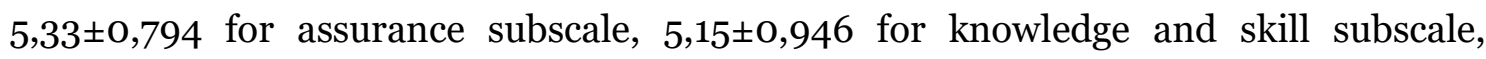
$5,27 \pm 0,747$ for respect subscale, $5,08 \pm 0,876$ for adherence subscale and care behaviors inventory total mean score was 5,22 $\pm 0,702$ (Table 2).

Table 2. Care Behaviors Inventory mean scores of the students $(n=651)$

\begin{tabular}{|l|l|l|l|l|l|}
\hline Subscales & Minimum & Maximum & $\mathbf{X}$ & SD & $\begin{array}{l}\text { Cronbach's } \\
\text { Alpha }\end{array}$ \\
\hline Assurance & 1.13 & 13.13 & 5.33 & .794 & .898 \\
\hline Knowledge Skill & 1.00 & 18.00 & 5.15 & .946 & .928 \\
\hline Respect & 1.00 & 6.00 & 5.27 & .747 & .883 \\
\hline Adherence & 1.00 & 12.80 & 5.08 & .876 & .900 \\
\hline Care Behaviors Inventory Total & 1.58 & 8.50 & 5.22 & .702 & 0.91 \\
\hline
\end{tabular}

$\mathrm{X}$ : mean, SD: standard deviation

In order to determine if the Care Behaviors Inventory total score and subscale mean scores of the students included in the study showed a significant difference according to variables of gender, education status, marital status, nationality, the status of having a child and family type, Mann Whitney U Test and Kruskal-Wallis $\mathrm{H}$ tests were conducted. As a result of the test, a statistically significant difference $(p<0.05)$ was found in the knowledge and skill subscale according to gender, in the assurance and respect subscales according to educational background and in the adherence subscale according to nationality. Hence, the difference was induced by the male gender, by the mean scores 
of the first-year students, and by the highest scores of the Turkish Cypriot students, followed by the scores of Turkish students and the scores of the foreign students were the least. No significant difference was found between the other variables and scale scores ( $p>0.05)$ (Table 3).

Table 3. Comparison of descriptive characteristics and care behaviors inventory mean scores of the students $(n=651)$

\begin{tabular}{|c|c|c|c|c|c|c|c|c|c|c|}
\hline \multirow[b]{2}{*}{ Gender } & \multicolumn{2}{|c|}{ Assurance } & \multicolumn{2}{|c|}{$\begin{array}{l}\text { Knowledge- } \\
\text { skill }\end{array}$} & \multicolumn{2}{|c|}{ Respect } & \multicolumn{2}{|c|}{ Adherence } & \multicolumn{2}{|c|}{ Scale Total } \\
\hline & $\bar{X}$ & SD & $\bar{X}$ & SD & $\bar{X}$ & SD & $\bar{X}$ & SD & $\bar{X}$ & $\mathrm{~S}$ \\
\hline Female & $5 \cdot 34$ & .693 & 5.12 & .978 & $5 \cdot 30$ & .687 & 5.08 & .876 & 5.23 & .666 \\
\hline Male & 5.27 & .822 & 5.23 & .782 & 5.20 & .870 & 5.06 & .874 & 5.20 & .770 \\
\hline $\mathbf{U}$ & \multicolumn{2}{|c|}{41.449} & \multicolumn{2}{|c|}{46.582} & \multicolumn{2}{|c|}{40.204} & \multicolumn{2}{|c|}{42.423} & \multicolumn{2}{|c|}{42.750} \\
\hline $\mathbf{p}$ & \multicolumn{2}{|l|}{.868} & \multicolumn{2}{|c|}{.024} & \multicolumn{2}{|l|}{.451} & \multicolumn{2}{|l|}{.769} & \multicolumn{2}{|l|}{.656} \\
\hline Nationality & $\bar{X}$ & SD & $\bar{X}$ & SD & $\bar{X}$ & SD & $\bar{X}$ & SD & $\bar{X}$ & SD \\
\hline Turk & $5 \cdot 37$ & .652 & 5.15 & .982 & 5.29 & .706 & 5.13 & .739 & 5.25 & .647 \\
\hline $\begin{array}{l}\text { Turkish } \\
\text { Cypriot }\end{array}$ & $5 \cdot 32$ & .761 & 5.09 & .901 & $5 \cdot 36$ & .695 & $5 \cdot 31$ & .984 & 5.28 & .677 \\
\hline Foreigner & 5.21 & .853 & 5.20 & .831 & 5.18 & .832 & 4.83 & 1.01 & 5.12 & .792 \\
\hline K-WH & \multicolumn{2}{|c|}{1.770} & \multicolumn{2}{|c|}{4.189} & \multicolumn{2}{|c|}{2.508} & \multicolumn{2}{|c|}{12.598} & \multicolumn{2}{|c|}{2.016} \\
\hline $\mathbf{P}$ & \multicolumn{2}{|l|}{.413} & \multicolumn{2}{|l|}{.123} & \multicolumn{2}{|l|}{.285} & \multicolumn{2}{|l|}{.002} & \multicolumn{2}{|l|}{.365} \\
\hline $\begin{array}{l}\text { Marital } \\
\text { Status }\end{array}$ & $\bar{X}$ & $\mathrm{SD}$ & $\bar{X}$ & SD & $\bar{X}$ & SD & $\bar{X}$ & SD & $\bar{X}$ & SD \\
\hline Married & 4.87 & 1.19 & 4.86 & 1.07 & 4.85 & 1.096 & 5.08 & .773 & 4.91 & .986 \\
\hline Single & $5 \cdot 33$ & .715 & 5.16 & .92 & 5.28 & .730 & 5.07 & .878 & 5.23 & .687 \\
\hline $\mathbf{U}$ & \multicolumn{2}{|c|}{3.083} & \multicolumn{2}{|l|}{.793} & \multicolumn{2}{|c|}{4.973} & \multicolumn{2}{|l|}{.999} & \multicolumn{2}{|c|}{2.087} \\
\hline $\mathbf{P}$ & \multicolumn{2}{|l|}{.214} & \multicolumn{2}{|l|}{.673} & .083 & & .607 & & .352 & \\
\hline $\begin{array}{l}\text { Do you } \\
\text { have } \\
\text { children }\end{array}$ & $\bar{X}$ & SD & $\bar{X}$ & SD & $\bar{X}$ & $\mathrm{SD}$ & $\bar{X}$ & SD & $\bar{X}$ & SD \\
\hline Yes & 5.44 & .583 & $5 \cdot 35$ & .678 & 5.42 & .790 & $5 \cdot 35$ & .741 & 5.40 & .619 \\
\hline No & $5 \cdot 32$ & .735 & 5.15 & .937 & 5.27 & .741 & 5.07 & .878 & 5.22 & .697 \\
\hline $\mathbf{U}$ & 5.531 & & 5.016 & & 4.83 & & 4.549 & & 4.828 & \\
\hline $\mathbf{P}$ & .563 & & .222 & & .147 & & .072 & & .148 & \\
\hline
\end{tabular}




\begin{tabular}{|l|l|l|l|l|l|l|l|l|l|l|}
\hline $\begin{array}{l}\text { Education } \\
\text { Status }\end{array}$ & $\bar{X}$ & $\mathrm{SD}$ & $\bar{X}$ & $\mathrm{SD}$ & $\bar{X}$ & $\mathrm{SD}$ & $\bar{X}$ & $\mathrm{SD}$ & $\bar{X}$ & $\mathrm{SD}$ \\
\hline $\mathbf{1}^{\text {st }}$ Year & 5.43 & .715 & 5.09 & .908 & 5.36 & .730 & 5.14 & .762 & 5.28 & .664 \\
\hline $\mathbf{2}^{\text {nd }}$ Year & 5.28 & .775 & 5.09 & .770 & 5.33 & .721 & 5.11 & .772 & 5.22 & .681 \\
\hline $\mathbf{3}^{\text {rd }}$ Year & 5.35 & .670 & 5.16 & .728 & 5.27 & .739 & 5.05 & .854 & 5.23 & .653 \\
\hline $\mathbf{4}^{\text {th } \text { Year }}$ & 5.22 & .774 & 5.26 & 1.32 & 5.14 & .768 & 5.03 & 1.08 & 5.17 & .799 \\
\hline K-WH & 8.028 & & 2.398 & & 8.096 & & 2.753 & 2.007 & \\
\hline P & .045 & & .494 & & .044 & & .571 & .045 & \\
\hline Family type & $\bar{X}$ & $\mathrm{SD}$ & $\bar{X}$ & $\mathrm{SD}$ & $\bar{X}$ & $\mathrm{SD}$ & $\bar{X}$ & $\mathrm{SD}$ & $\bar{X}$ & SD \\
\hline Nuclear & 5.30 & .737 & 5.14 & .9799 & 5.27 & .736 & 5.06 & .907 & 5.21 & .704 \\
\hline Extended & 5.41 & .658 & 5.21 & .771 & 5.31 & .717 & 5.17 & .726 & 5.29 & .629 \\
\hline $\begin{array}{l}\text { Single } \\
\text { parent }\end{array}$ & 5.24 & .860 & 5.13 & .759 & 5.17 & .853 & 4.91 & .854 & 5.13 & .750 \\
\hline $\begin{array}{l}\text { Broken } \\
\text { family }\end{array}$ & $5 \cdot 35$ & .743 & 5.13 & 1.100 & 5.25 & 1.083 & 5.23 & 1.127 & 5.25 & .974 \\
\hline $\begin{array}{l}\text { Living } \\
\text { alone }\end{array}$ & $5 \cdot 31$ & .088 & 5.60 & .282 & 5.66 & .235 & 5.40 & .000 & 5.47 & .029 \\
\hline K-WH & 3.732 & & 2.707 & & 1.144 & 4.040 & 2.987 & & 3.732 & \\
\hline P & .444 & & .608 & & .887 & .401 & .560 & & .444 & \\
\hline
\end{tabular}

K-W H: Kruskal-Wallis H Test, U: Mann Whitney U Test

Mann Whitney $\mathrm{U}$ and Kruskal-Wallis $\mathrm{H}$ tests were applied to determine if the Care Behaviors Inventory total score and subscale mean scores of the students included in the study showed a significant difference according to the variables of "previous hospitalization, the experience of working as a nurse, choosing nursing profession again if they had another chance, taking care of an elderly/baby/patient before, feeling competent about understanding patients, and preferring a student nurse by their own willingness. As a result of the test, a statistically significant difference was found between the scale total score and subscale mean scores and the variables of "preferring nursing profession again, feeling competent about understanding patients, and preferring to be a student nurse by their own willingness" ( $p<0.05)$. The difference was found to be caused by the high mean scores of the participants who responded "yes". No significant difference was found between the other variables and scale scores ( $p>0.05$ ) (Table 4 ). 
Table 4. Comparison of the students' views on profession and Care Behaviors Inventory mean scores $(n=651)$

\begin{tabular}{|c|c|c|c|c|c|c|c|c|c|c|}
\hline \multirow[b]{2}{*}{$P H$} & \multicolumn{2}{|c|}{ Assurance } & \multicolumn{2}{|c|}{$\begin{array}{l}\text { Knowledge- } \\
\text { skill }\end{array}$} & \multicolumn{2}{|c|}{ Respect } & \multicolumn{2}{|c|}{ Adherence } & \multicolumn{2}{|c|}{ Scale Total } \\
\hline & $\bar{X}$ & SD & $\bar{X}$ & SD & $\bar{X}$ & SD & $\bar{X}$ & SD & $\bar{X}$ & $\mathrm{~S}$ \\
\hline Yes & 5.44 & .583 & $5 \cdot 35$ & .678 & 5.42 & .790 & $5 \cdot 35$ & .741 & 5.40 & .619 \\
\hline No & $5 \cdot 32$ & .735 & 5.15 & .937 & 5.27 & .741 & 5.07 & .878 & 5.22 & .697 \\
\hline $\mathbf{U}$ & \multicolumn{2}{|c|}{5.016} & \multicolumn{2}{|c|}{5.079} & \multicolumn{2}{|c|}{5.139} & \multicolumn{2}{|c|}{5.128} & \multicolumn{2}{|c|}{5.037} \\
\hline $\mathbf{p}$ & \multicolumn{2}{|l|}{.300} & \multicolumn{2}{|l|}{.438} & \multicolumn{2}{|l|}{.603} & \multicolumn{2}{|l|}{.571} & \multicolumn{2}{|l|}{.344} \\
\hline SHEAN & $\bar{X}$ & SD & $\bar{X}$ & SD & $\bar{X}$ & $\mathrm{SD}$ & $\bar{X}$ & $\mathrm{SD}$ & $\bar{X}$ & SD \\
\hline Yes & $5 \cdot 32$ & .788 & 5.27 & .699 & 5.19 & .854 & 4.96 & .901 & 5.20 & .725 \\
\hline No & $5 \cdot 32$ & .721 & 5.13 & .965 & 5.29 & .721 & 5.09 & .869 & 5.22 & .690 \\
\hline $\mathbf{U}$ & \multicolumn{2}{|c|}{2.654} & \multicolumn{2}{|c|}{2.380} & \multicolumn{2}{|c|}{2.546} & \multicolumn{2}{|c|}{2.480} & \multicolumn{2}{|c|}{2.655} \\
\hline$\overline{\mathbf{P}}$ & \multicolumn{2}{|l|}{.894} & \multicolumn{2}{|l|}{.079} & \multicolumn{2}{|l|}{.441} & \multicolumn{2}{|l|}{.245} & \multicolumn{2}{|l|}{.899} \\
\hline SSNPAIAC & $\bar{X}$ & SD & $\bar{X}$ & SD & $\bar{X}$ & SD & $\bar{X}$ & SD & $\bar{X}$ & SD \\
\hline Yes & $5 \cdot 36$ & .711 & 5.20 & .800 & $5 \cdot 32$ & .730 & 5.14 & .886 & 5.27 & .674 \\
\hline No & 5.24 & .765 & 5.06 & 1.145 & 5.17 & .759 & 4.94 & .841 & 5.12 & .729 \\
\hline $\mathbf{U}$ & \multicolumn{2}{|c|}{41.393} & \multicolumn{2}{|c|}{39.329} & \multicolumn{2}{|c|}{39.590} & \multicolumn{2}{|c|}{40.230} & 39.19 & \\
\hline$\overline{\mathbf{P}}$ & .014 & & .001 & & .001 & & .003 & & .001 & \\
\hline STCВEPB & $\bar{X}$ & SD & $\bar{X}$ & SD & $\bar{X}$ & SD & $\bar{X}$ & $\mathrm{SD}$ & $\bar{X}$ & SD \\
\hline Yes & 5.29 & .740 & 5.15 & .786 & 5.24 & .766 & 5.03 & .968 & 5.19 & .702 \\
\hline No & $5 \cdot 36$ & .717 & 5.16 & 1.09 & $5 \cdot 32$ & .708 & 5.13 & .735 & 5.26 & .685 \\
\hline $\mathbf{U}$ & 4.855 & & 5.09 & & 4.873 & & 4.932 & & 4.912 & \\
\hline $\mathbf{P}$ & .132 & & .608 & & .153 & & .239 & & .209 & \\
\hline SFCAUP & $\bar{X}$ & $\mathrm{SD}$ & $\bar{X}$ & SD & $\bar{X}$ & SD & $\bar{X}$ & $\mathrm{SD}$ & $\bar{X}$ & SD \\
\hline Always & 5.44 & .753 & $5 \cdot 31$ & .792 & 5.42 & .761 & 5.25 & .956 & $5 \cdot 37$ & .712 \\
\hline Sometimes & 5.23 & .677 & 5.04 & 1.01 & 5.15 & .699 & 4.94 & .762 & 5.11 & .649 \\
\hline Never & 4.82 & 1.136 & 4.48 & 1.084 & 4.88 & .777 & 4.64 & 1.042 & 4.72 & .846 \\
\hline K-WH & 34.29 & & 40.12 & & 45.19 & & 36.88 & & 53.72 & \\
\hline$\overline{\mathbf{P}}$ & .000 & & .000 & & .000 & & .000 & & .000 & \\
\hline SCSNBTOW & $\bar{X}$ & SD & $\bar{X}$ & $\mathrm{SD}$ & $\bar{X}$ & $\mathrm{SD}$ & $\bar{X}$ & $\mathrm{SD}$ & $\bar{X}$ & SD \\
\hline
\end{tabular}




\begin{tabular}{|c|c|c|c|c|c|c|c|c|c|c|}
\hline Yes & $5 \cdot 36$ & .679 & 5.187 & .768 & $5 \cdot 33$ & .695 & 5.14 & .846 & 5.27 & .637 \\
\hline No & 5.08 & .929 & 5.00 & 1.52 & 4.99 & .905 & 4.75 & .957 & 4.97 & .909 \\
\hline$\overline{\mathbf{U}}$ & \multicolumn{2}{|c|}{22.774} & \multicolumn{2}{|c|}{22.836} & \multicolumn{2}{|c|}{20.991} & \multicolumn{2}{|c|}{21.331} & \multicolumn{2}{|c|}{21.357} \\
\hline $\mathbf{P}$ & \multicolumn{2}{|c|}{.002} & \multicolumn{2}{|c|}{.002} & .000 & & \multicolumn{2}{|c|}{.000} & \multicolumn{2}{|l|}{.000} \\
\hline
\end{tabular}

K-W H: Kruskal-Wallis H Test, U: Mann Whitney U Test

* PH; Previous hospitalization, SHEAN; Status of having experience as a nurse, SSNPAIAC; Status of selecting nursing profession again if he/she had another chance, STCBEPB; Status of taking care of a baby/elderly or a patient before, SFCAUP; Status of feeling competent about understanding patients, SCSNBTOW; Status of choosing to be a student nurse by their own willingness.

\section{Discussion}

Nursing care is a service that all individuals in society will need in any period of their lives, and it is an important quality indicator of health services. In order to provide quality care which is under the responsibility of nurses, they should have necessary information and skills and care should be sensitive in terms of human and ethical aspects $^{14}$. Since nursing students are the potential nurses of the future, they are expected to have appropriate care behaviors in addition to appropriate academic qualifications. While the education process provides a positive change in helping nursing students to gain care behaviors, it is stated that this change is sometimes not positive ${ }^{9}$. Therefore, this study was conducted to determine the care behavior perceptions of nursing students, the influencing factors and whether or not there was a difference between the students' care behavior perceptions.

According to the study results, the CBI-24 total mean score of the students was high $(5,22 \pm 0,702)$. This showed that students' perceptions about care were positive. Similarly, it was stated in other studies that student nurses had high care perceptions ${ }^{14-}$ ${ }^{16}$. In the present study, high care behavior perception of student nurses showed that care concept was attached importance in education and the students were supported to develop these behaviors. The students also obtained high scores on the subscales of the CBI-24. It was determined that they obtained the highest score from the assurance subscale; whereas, the lowest score was from the adherence subscale. High score of assurance subscale in the study showed that the nurses performed their roles well in the 
subjects like going to the patient willingly, meeting their needs, reducing their pain, performing their treatment on time and relieving their symptoms. In the study conducted by Labrague et. al. to investigate care behavior perceptions of 586 nursing students, they stated that the students received the highest score from the assurance subscale $^{17}$. Low score obtained from adherence subscale indicated that student nurses can not fully fulfill their important roles and responsibilities about informing, training patient by sparing time for him/her, and ensuring patient's involvement in care planning. When different studies conducted with nurses are examined, it was concluded that "nurses did not fully perform activities such as training, informing that will contribute to the development of the patient by sparing more time for him/her" which is similar to the results of the present study ${ }^{18-20}$. However, when the different studies conducted with nurses in clinics and student nurses were examined, it was seen that while the highest score was obtained mostly in the knowledge-skill subscale, the lowest score was obtained in the adherence subscale ${ }^{14,21,22}$. Similar to the present study, it was stated in the study conducted by Turk G. et al. with 673 nursing students that the highest score was observed in the assurance subscale and the lowest scores were observed in knowledge-skill and adherence subscales ${ }^{23}$. The fact that the knowledge skill subscale was lower than the assurance and respect subscales may be related with crowded clinical practice areas, fewer hours of clinical practice due to difficulties in admitting students in clinical areas, and less involvement of students in clinical practice due to the malpractice concerns. The high score of assurance subscale showed that the students loved the profession, adopted the patient and cared about the patient. This may also mean that the student nurses were very sensitive about the real and perceived needs and expectations of the patients. In the literature, it is stated that the sense of holistic care is a concept containing affective, cognitive and psychomotor skills and having a moral dimension based on mutual trust ${ }^{15,19}$. Therefore, high scores of the students from the overall scale and its subscales are a pleasing result showing that they have adopted the care concept.

When the students' descriptive characteristics and CBI-24 mean scores were compared, male students had significantly higher knowledge-skill subscale scores than female students. The effect of gender on care perception has been examined in various studies. Some studies concluded that there was a difference in favor of women ${ }^{23,24}$. while some other studies revealed that gender did not cause any difference ${ }^{14,16}$. We can attribute the 
higher score of men from knowledge-skill subscale as a result of the present study to the effort of showing that men can also do the nursing profession predominantly done by women as well as women do. When the social perception related to the nursing profession in the past is evaluated, it was accepted as a profession that was considered as appropriate to women mainly because of its caregiving role and today, the number of male students preferring this profession is increasing every year. In addition, the acceptance rate of male nurses in society increases and the sexist approach in the nursing profession also decreases ${ }^{25}$. The fact that there was no difference in the other subscales of the scale showed that both genders comprehended that the care concept is very important in the nursing profession.

A significant difference was determined in the adherence subscale based on nationality. It was determined that the difference based on nationality was caused by higher scores of Turkish Cypriots than Turkish students and higher scores of Turkish students than foreign students. While Turkish Cypriot students got the highest score in adherence subscale, foreign students received the lowest score. Differences in care behaviors reported by the student nurses are an evidence indicating that the care expression varies by culture. According to the report by Labrague et al. ${ }^{17}$, Leininger 5 stated that care is a universal phenomenon but expressions, processes and patterns differ between cultures ${ }^{17}$. In the same study, it was also stated that the students found psychological skills more important than practical behaviors ${ }^{17}$. In the study conducted by Omari et al. with 150 patients and 60 nurses in the coronary care unit in Jordan, the nurses reported that they perceived the psychological aspects of care as important care behaviors ${ }^{26}$.

Khademian and Vizeshfar determined that the students in a nursing program based on a university in Iran perceived physical-based care behaviors as more important but emotional behaviors as less important care behaviors ${ }^{27}$. Differences in the studies showed that there are differences in students' care behavior perceptions depending on cultures.

Another significant difference in this study was that assurance and respect subscale mean scores of the first-year students were higher. In another study investigating the effect of nursing education on care behaviors of nursing students, the scores of third-year students were found to be lower than the first-year student 9 . However, in the study by 
Turk et al. the scores of fourth-year students were found to be higher unlike the results of the present study ${ }^{23}$. The fact that the students get lower scores from this subscale as the year increases should be carefully monitored by nurse educators and clinical managers. As the education period increases and the time spent with the patient in the clinic prolongs, the presence of the difference in knowledge-skill subscale is a natural result of the education activity. In fact, it was stated in a study examining the nursing students' understanding of care science that the students deepened in understanding care science in the last year of their education ${ }^{28}$.

In the comparison made between the nursing students' responses to the questions about the profession other than their descriptive characteristics and overall CBI-24 scale and its subscales, the scores of the students who preferred the profession by their own willingness and said to select nursing profession again if they had another chance and felt competent about understanding the patients were found to be significantly high. If an individual chooses his/her profession willingly, this enables him/her to fulfill the functions of the profession by adopting the behaviors and responsibilities specific to that profession and to satisfy with the service he/she provides. In the study conducted by Birimoğlu and Ayaz $^{16}$ to determine their care behavior perceptions, they reported that the scores of the students who selected the profession willingly were higher ${ }^{16}$. In another study, it was emphasized that the students who chose the nursing profession by their wishes and interest were more successful in clinical practices than the others and got more satisfaction from their profession ${ }^{29}$. The results obtained from this study seem to be compatible with the literature. Considering that the student nurses will be the future nurses, it can be asserted that doing the job lovingly and willingly will increase the quality of care and therefore, patient satisfaction will increase. Therefore, it is necessary to help nursing students in gaining care behaviors during education and to follow-up and improve after their graduation.

\section{Conclusion}

It was determined that the care behaviors perceptions of the students were in a good level and the students' care behavior perceptions were affected by the factors like gender, nationality, class variable and preferring the profession willingly. In line with these results; it can be recommended to ensure that students willingly prefer the profession, to 
conduct practices in providing the continuity of positive care behaviors of the students during the nursing education process and to conduct the study with a larger sample and by adding new variables with different sample groups.

\section{Limitations of the Study}

Since the research was conducted with the Nursing Department students in only two centers, the results obtained from the research can only be generalized for these students.

\section{REFERENCES}

1. Dalpezzo NK. Nursing care: a concept analysis. Nursing Forum. 2009;44(4):256264. doi:10.1111/j.1744-6198.2009.00151.x.

2. Gul S. Nursing care in the light of care concept and affecting factors. Journal of Acibadem University Health Science. 2019;10(2):129-134. doi:10.31067/0.2019.134.

3. Li YS, Yu WP, Yang BH, Liu CF. A comparison of the caring behaviours of nursing students and registered nurses: implications for nursing education. Journal of Clinical Nursing. 2016;25(21-22):3317-3325. doi: 10.1111/jocn.13397.

4. Akın Korhan E, Lydia H. Self, Treatment and Care Theory. In: Karadağ A, Çalışkan N, Göçmen Baykara Z, eds. Nursing Theories and Models. 1st eds. İstanbul: Academy Inc; 2017:300-325.

5. McFarland M, Leininger M. Culture Care Theory of Diversity and Universality. In: Tomey AM, Alligood MR, eds. Nursing Theorists and Their Work. 6nd ed. St. Louis Missouri: Mosby Inc; 2006:472-496.

6. Pokerny ME. Nursing Theorists of Historical Significance. In: Alligood MR, ed. Nursing Theorists and Their Work. 9nd ed. St. Louis Missouri: Mosby Inc; 2013:14-15.

7. Khouri R. Impact of an educational program on nursing students' caring and selfperception in intensive clinical training in Jordan. Advances in Medical Education and Practice. 2011;2:173-185. doi: 10.2147/AMEP.S65465. 
8. Bassett C. Educating for care: a review of the literature. Nurse Education Practice. 2001;1(2):64-72. doi: 10.1054/nepr.2001.0009.

9. Murphy F, Jones S, Edwards M, James J, Mayer A. The impact of nurse education on the caring behaviours of nursing students. Nurse Education Today. 2009;29(2):254-264. doi: 10.1016/j.nedt.2008.08.016.

10. Mlinar S. First-and third-year student nurses' perceptions of caring behaviours. Nursing Ethics. 2010;17(4):491-50o. https://doi.org/10.1177/0969733010364903.

11. Wu Y, Larrabee JH, Putman HP. Caring behaviors inventory: a reduction of the 42item instrument. Nursing Research. 2006;55(1):18-25. doi: 10.1097/00006199200601000-00003.

12. Kursun S, Kanan N. Validity and reliability study of the Turkish version of caring behaviors inventory-24. Journal of Anatolia Nursing and Health Sciences. 2012;15(4):229-235.

13. Cosansu G. Some concepts related to data analysis. In; Erdoğan S, Nahcivan N, Esin N, eds. Research in Nursing Process, Application and Critical. 4. Eds. Istanbul: Nobel Medical Bookstore; 2014:237-279.

14. Erenoglu R, Can R, Tambag H. Tambag H. Nursing care behaviors and factors related to care behaviors; maternity hospital. Health and Society. 2019;29(1):7988.

15. Papastavrou E, Efstathiou G, Tsangari H, et. al. A cross-cultural study of the concept of caring through behaviours: patients' and nurses' perspectives in six different EU countries. Journal of Advanced Nursing . 2012;68(5):1026-1037. doi:10.1111/j.1365-2648.2011.05807.x2012;68:1026-1037.

16. Birimoglu C, Ayaz S. Nursing students' perceptions of caring behaviors. Journal of Hacettepe University Faculty of Nursing. 2015;2(3):40-48.

17. Labrague LJ, McEnroe-Petitte DM, Papathanasiou IV, Edet OB, Arulappan J. Impact of instructors' caring on students' perceptions of their own caring behaviors. Journal of Nursing Scholarship. 2015;47(4): 338-346. doi: 10.1111/jnu.12139. 
18. He T, Du Y, Wang L, Zhong ZF, Ye XC, Liu XH. Perceptions of caring in China: patient and nurse questionnaire survey. International Nursing Review. 2013;6o(84):487-493. https://doi.org/10.1111/inr.12058.

19. Cerit B, Coskun S. Patients' and nurses' perceptions relating to the nursing care quality. Turkish Journal of Clinics Laboratory. 2018;9(2):103-109. doi:10.18663/tjcl.380674.

20. Korlou C, Papathanassoglou E, Patiraki E. Caring behaviors in cancer care in Greece, comparison of patients', their caregivers' and nurse's perceptions. European Journal of Oncology Nursing . 2015;19(3):244-250. doi: 10.1016/j.ejon.2014.11.005.

21. Burtson PL, Stichler JF. Nursing work environment and nurse caring: relationship among motivational factors. Journal of Advanced Nursing . 2010;66(8):1819-1831. doi:10.1111/j.1365-2648.2010.05336.x.

22. Demirbag BC, Kurt Y, Ozkan CG, Bayrak B, Kavgacı A, Ozbey H. The determination of the care behaviours of nurses and its evaluation by patients. Malasian Journal of Nursing. 2018;9(3):61-69.

23. Turk G, Adana F, Erol F, Cevik R, Akyıl Cevik R, Taşkıran N. The reasons for choosing the career of the nursing students and their perceptions of care behaviours. Gumushane University Journal of Health Sciences. 2018;7(3):1-10.

24. Codier E, MacNaughton NS. Are male nurses emotionally intelligent? Nursing Management. 2012;43(4):1-4. doi: 10.1097/01.NUMA.oooo413355.36765.b1.

25. Arslan A, Agacdiken Alkan S. Female nurse perception among university students. Journal of Samsun Health Sciences. 2016;1(1):146-166.

26. Omari FH, AbuAlRub R, Ayasreh IR. Perceptions of patients and nurses towards nurse caring behaviors in coronary care units in Jordan. Journal of Clinical Nursing. 2013;22(21-22):3183-3191. doi:10.1111/jocn.12458.

27. Khademian Z, Vizeshfar F. Nursing students' perceptions of the importance of caring behaviors. Journal of Advanced Nursing. 2008;61(4):456-462. doi:10.1111/j.1365-2648.2007.04509.x. 
28. Eklund-Myrskog ED. Student nurses' understanding of caring science. Nurse Education Today. 2000;20(2):164-170. doi:10.1054/nedt.1997.0445.

29. Safadi RR, Saleh MYN, Nassar OS, Amre HM, Froelicher ES. Nursing students' perceptions of nursing: a descriptive study of four cohorts. International Nursing Review. 2011;58(4):420-427. doi:10.1111/j.1466-7657.2011.00897.x. 